\title{
MENUMBUHKAN DAYA NALAR ( POWER OF REASON ) SISWA MELALUI PEMBELAJARAN ANALOGI MATEMATIKA
}

\author{
Oleh : \\ Rahayu Kariadinata \\ Pengajar pada Program Studi Pendidikan Matematika \\ Fakultas Tarbiyah dan Keguruan Universitas Islam Negeri (UIN) - Bandung \\ E-mail : rahayu61@yahoo.com,
}

\begin{abstract}
Abstrak
Pembelajaran analogi matematika merupakan salah satu alternatif pembelajaran yang dapat diterapkan dalam rangka menumbuhkan daya nalar (power of reason) siswa. Melalui analogi matematika siswa dituntut untuk dapat mencari keserupaan atau keterkaitan sifat dari dua konsep yang sama atau berbeda melalui perbandingan, selanjutnya menarik suatu kesimpulan dari keserupaan tersebut. Dengan demikian analogi dapat digunakan sebagai penjelasan atau sebagai dasar penalaran. Sebelum memulai pembelajaran analogi matematika, sebaiknya guru memeriksa kemampuan pemahaman konsep matematika siswa, karena tingkat pemahaman siswa akan berpengaruh kepada daya nalarnya. Tugas (soal-soal) analogi matematika termasuk soal non rutin, oleh karenanya diperlukan kesiapan guru dalam membuatnya. Pada setiap soal analogi matematika termuat konsep yang sama atau berbeda, sehingga dibutuhkan materi yang cukup banyak. Langkah-langkah membuat soal analogi matematika, adalah : a) susunlah semua konsep dalam matematika yang telah dipelajari siswa ; b) susun pula sifat-sifat / hubungan yang terdapat dalam setiap konsep, dan c) pilih materi-materi yang mempunyai sifat / hubungan yang dapat dianalogikan. Dalam tulisan ini diberikan dua bentuk soal analogi matematika yaitu analogi matematika model 1 dan analogi matematika model 2. Pembelajaran analogi matematika sebaiknya dilaksanakan setelah sejumlah konsep dipelajari. Ada baiknya diberikan di kelas-kelas akhir karena banyak konsep yang telah dipelajari oleh siswa. Daya nalar (power of reason) siswa menjadi bagian penting dalam proses pembelajaran untuk mengantarkan mereka menuju masa depannya sebagai warga negara yang cerdas, yang akan dipimpin oleh daya nalar (otak) dan bukan dengan kekuatan (otot) saja. Sebagaimana dikemukakan oleh mantan Presiden AS Thomas Jefferson (dalam Copi,1978:vii) yang menyatakan: "In a republican nation, whose citizens are to be led by reason and persuasion and not by force, the art of reasoning becomes of first importance"
\end{abstract}

Kata kunci : Daya nalar, analogi matematika

\section{A. Pendahuluan}

Menghadapi perkembangan ilmu pengetahuan dan teknologi yang begitu pesat saat ini, diperlukan sumber daya manusia yang handal dan mampu berkompetisi secara global. Kompetisi akan menjadi prinsip hidup dalam suatu masyarakat, karena keadaan dunia yang terbuka dan bersaing untuk mengejar kualitas dan keunggulan. Kesemuanya ini menuntut setiap insan memerlukan 
kemampuan berpikir. Kemampuan manusia beradaptasi dilandasi oleh kemampuan berpikirnya yang melahirkan teknologi dan bentuk kehidupan sosial budayanya (Rustaman, 1990:1).

Dengan demikian pengembangan SDM saat ini harus di titik beratkan pada kemampuan berpikir, yang melibatkan pemikiran krirtis, sistematis, logis, dan kreatif. Dalam suatu proses kegiatan berpikir memerlukan pemahaman terhadap masalah yang berhubungan dengan materi yang sedang dipikirkan, kemampuan dalam bernalar (reason), kemampuan intelektual , imajinasi, dan keluwesan (fleksibilitas) dari pikiran yang merentang kedalam hasil pemikiran (Gosev dan Safuanov, dalam Dahlan , 2004: 2)

Penalaran (reasoning) merupakan salah satu aspek dari kemampuan berpikir matematik tingkat tinggi dalam kurikulum terbaru, yang dikategorikan sebagai kompetensi dasar yang harus dikuasai para siswa. Dalam kegiatan pembelajaran, aktivitas matematika merupakan sarana bagi siswa untuk dapat memecahkan suatu permasalahan melalui logika nalar mereka. Melalui aktivitas bernalar siswa dilatih untuk menarik suatu kesimpulan atau membuat suatu pernyataan baru berdasarkan pada beberapa fakta. Sehingga pada saat belajar matematika, para siswa akan selalu berhadapan dengan proses penalaran.

Daya nalar dan logika merupakan salah satu kemampuan penting dan keterampilan yang perlu dimiliki dan merupakan fitrah dari manusia. dengan logika ini, manusia berpikir dan membedakan mana yang benar dan salah. Dengan daya nalar manusia mampu berpikir untuk terus mempertahankan kelangsungan hidupnya dan keturunannya. Dengan daya nalar ini manusia dapat berkreasi dan menciptakan teknologi yang dapat mempermudah kehidupannya. Dengan daya nalar ini manusia terus berkembang dan meningkatkan kemampuannya dalam beradaptasi dengan lingkungan yang dinamis dan berubah secara kontinu.

Berdasarkan uraian di atas, muncul suatu pertanyaan : "Bagaimana menumbuhkan daya nalar (power of reason) siswa" ? Berbagai upaya telah dilakukan, diantaranya dengan digelarnya berbagai kompetisi matematika yang bertujuan untuk menguji kemampuan dan daya nalar siswa. Daya nalar merupakan modal utama dalam mempersiapkan mereka menghadapi persaingan yang sangat ketat di masa datang. Semakin tajam daya nalar seseorang maka ia akan semakin mampu menghadapi tantangan hidup. Daya nalar siswa juga terkait dengan tujuan formal, yaitu penataan nalar siswa untuk diterapkan dalam kehidupannya (Depdiknas, 2001: 8)

Seni bernalar memang sangat dibutuhkan dalam setiap segi dan setiap sisi kehidupan, agar setiap warga negara dapat menunjukkan dan menganalisis setiap masalah, dapat memecahkan masalah dengan tepat, dapat menilai 
sesuatu secara kritis dan objektif, serta dapat mengemukakan pendapat maupun ideanya secara runtut dan logis (Shadiq,2007). Daya nalar (power of reason) siswa menjadi bagian penting dalam proses pembelajaran untuk mengantarkan mereka menuju masa depannya sebagai warga negara yang cerdas, yang akan dipimpin oleh daya nalar (otak) dan bukan dengan kekuatan (otot) saja. Dengan demikian tak dapat dipungkiri lagi bahwa pentingnya penalaran bagi setiap warga negara, baik bagi pemimpin, ilmuwan, birokrat, sampai ke rakyat biasa. Sebagaimana dikemukakan oleh mantan Presiden AS Thomam s Jefferson (dalam Copi,1978:vii) yang menyatakan : "In a republican nation, whose citizens are to be led by reason and persuasion and not by force, the art of reasoning becomes of first importance"

Pelajaran matematika diyakini mampu meningkatkan daya nalar. Dengan mempelajari matematika siswa akan terbiasa berpikir secara sistematis dan terstruktur karena siswa akan selalu dihadapkan pada pemecahan masalah, hubungan sebab akibat, pertanyaan dan jawaban yang logis, ilmiah, dan masuk akal. Pemecahan masalah dalam matematika biasa dilakukan secara terpola dan sistematis dengan mengikuti satu pola tertentu. Pentingnya daya nalar bagi siswa tertuang pula dalam Permendiknas 2006 yang menyebutkan bahwa siswa belajar matematika agar memiliki kemampuan menggunakan penalaran pada pola dan sifat. Namun kenyataannya banyak siswa yang kurang menggunakan penalaran dalam mempelajari pola dan sifat yang terdapat pada materi matematika,

Salah satu upaya menumbuhkan daya nalar (power of reason) siswa, dengan memberikan suatu bentuk pembelajaran yang lebih menekankan pada analogi matematika. Analogi merupakan salah satu bagian dari penalaran induktif. Melalui analogi, siswa dituntut untuk dapat mencari keserupaan atau keterkaitan sifat dari suatu konsep tertentu ke konsep lain melalui perbandingan.

Studi yang berkaitan dengan pembelajaran analogi matematika untuk mengembangkan kemampuan nalar siswa, diantaranya dilakukan oleh Alamsyah (2000) terhadap siswa MAN kelas 2 di Lampung, dengan menggunakan tes analogi, melaporkan bahwa kemampuan penalaran analogi matematika siswa meningkat secara signifikan setelah mendapat suatu pembelajaran yang menekankan pada penanaman konsep-konsep dan mengaitkan antar konsep. Selanjutnya, Kariadinata (2001) melalui penelitiannya terhadap siswa SMA kelas 1 di Bandung, melaporkan bahwa kemampuan analogi siswa mengalami peningkatan setelah mendapatkan pembelajaran kooperatif dengan pendekatan analogi, dan terdapat assosiasi yang cukup kuat antara pemahaman konsep matematika dan kemampuan analogi matematika siswa. 


\section{B. Kajian Pustaka}

\section{Daya Nalar (Power of Reason)}

Nalar atau penalaran (reasoning) adalah suatu proses berpikir pencapaian kesimpulan logis berdasarkan fakta dan sumber yang relevan ( Shurter dan Pierce dalam Utari,1987:31). Penalaran dapat juga diartikan sebagai proses berpikir yang bertolak dari pengamatan indera (observasi empirik) yang menghasilkan sejumlah konsep dan pengertian. Berdasarkan pengamatan yang sejenis juga akan terbentuk proposisi-proposisi yang sejenis.

Selanjutnya, berdasarkan sejumlah proposisi yang diketahui atau dianggap benar, orang menyimpulkan sebuah proposisi baru yang sebelumnya tidak diketahui. Proses inilah yang disebut menalar. Dalam penalaran, proposisi yang dijadikan dasar penyimpulan disebut premis (antesedens) dan hasil kesimpulannya disebut dengan konklusi (consequence). Sebagaimana dikemukakan oleh Copi (1978:5), " Reasoning is a special kind of thinking in which inference take place, in which conclusions are drawn from premises"

Daya nalar (power of reason) merupakan kekuatan memahami dan menarik suatu kesimpulan. Daya nalar juga merupakan pembentuk (cara berpikir) bukan sebagai bentukan (hasil pemikiran), sehingga dominasinya terletak pada kekuatan pengetahuan , teori dan sejumlah pengetahuan lain

\section{Pengertian Analogi}

Analogi dalam bahasa Indonesia ialah "kias" (dalam bahasa Arab, qasa = mengukur, membandingkan). Berbicara tentang analogi menurut Soekadijo (1997:139) adalah berbicara tentang dua hal yang berlainan, yang satu bukan yang lain, dan dua hal yang berlainan itu dibandingkan. Dalam mengadakan perbandingan kita mencari persamaan dan perbedaan antara keduanya. Jika dalam perbandingan itu orang hanya memperhatikan persamaannya saja tanpa melihat perbedaannya maka timbullah analogi persamaan (keserupaan) diantara dua hal yang berbeda, dan selanjutnya akan ditarik suatu kesimpulan atas dasar keserupaan tadi. Dengan demikian analogi dapat dimanfaatkan sebagai penjelasan atau sebagai dasar penalaran.

Dalam istilah peribahasa, kita sering menemukan kalimat "rambutnya indah bagaikan bunga mayang". Disini kita membandingkan dua hal yang berlainan yaitu rambut dan bunga mayang selanjutnya menganalogikan (membuat keserupaan) antara rambut yang indah dengan bunga mayang. Contoh lain, misalnya "wajah kedua anak kembar itu bagaikan pinang di belah dua". Dalam hal inipun kita membandingkan dua hal yang berlainan yaitu wajah dua anak kembar dan pinang selanjutnya menganalogikan (membuat keserupaan) antara wajah anak kembar dengan permukaan pinang yang dibelah dua. Kedua 
contoh ini dinamakan analogi non argumentatif,yaitu analogi yang tidak memerlukan alasan.

Analogi sering digunakan dalam tes potensi akademik, psikotes dan sejenisnya. Berikut contoh soal analogi

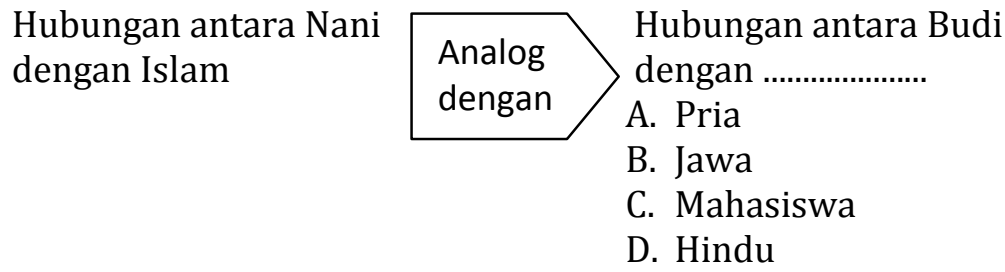

Alasan :

Disini kita membandingkan dua pernyataan (sebelah kiri dan kanan), kemudian mencari keserupaannya. Melalui suatu proses berpikir/pengamatan pada pernyataan sebelah kiri, didapat bahwa hubungan antara Nani dengan Islam merupakan hubungan antara manusia dengan keyakinannya (agama), hal ini analog (serupa) dengan hubungan antara Budi dengan Hindu (jawaban D). Sebagai alasan memilih jawaban D, karena analogi yang terjadi adalah analogi hubungan keyakinan (agama). Contoh ini dinamakan analogi argumentatif, yaitu analogi yang memerlukan alasan

Sedangkan dalam matematika, kita dapat membuat soal-soal analogi matematika, yang memuat konsep-konsep matematika yang memiliki keterkaitan sifat. Berikut contoh soal analogi matematika (dimodifikasi dari tes dalam Utari,1987)

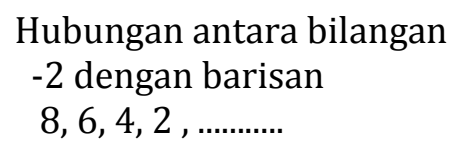

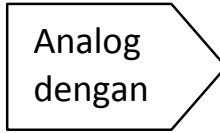

Hubungan antara $\mathrm{p}$ dengan barisan .....

A. $p+1, p+2, p+3, p+4, \ldots$

B. $\mathrm{p}, \mathrm{p}^{2}, \mathrm{p}^{3}, \mathrm{p}^{4}$,

C. $p, 2 p, 3 p, 4 p$,

D. $p-1, p-2, p-3, p-4, \ldots \ldots$

Alasan :

Melalui suatu proses berpikir pada pernyataan sebelah kiri, diperoleh bahwa hubungan antara -2 dengan barisan 8,6,4,2,........adalah hubungan sifat beda pada barisan aritmatika, analog (serupa dengan) hubungan antara $p$ dengan barisan $p, 2 p, 3 p, 4 p, \ldots \ldots \ldots . . . .(j a w a b a n ~ C)$, alasannya karena analogi yang terjadi adalah analogi sifat beda pada barisan aritmatika.

Analogi matematika, dapat membantu siswa untuk memahami suatu materi lain dengan mencari keserupaan sifat diantara materi yang dibandingkan. 
Untuk dapat menyelesaikan soal analogi matematika diperlukan pemahaman konsep yang baik.

\section{Pembelajaran Analogi Matematika}

Salah satu alternatif pembelajaran yang dapat diterapkan dalam upaya mengembangkan daya nalar (power of reason) siswa adalah pembelajaran analogi matematika. Pembelajaran ini lebih menekankan pada teknik analogi dalam matematika. Dengan bimbingan guru siswa dilatih daya nalarnya melalui proses berpikir untuk menemukan hubungan sifat suatu konsep dan mencari analoginya berdasarkan sifat tersebut.

Sebelum memulai pembelajaran analogi, sebaiknya guru memeriksa kemampuan pemahaman konsep matematika siswa, dan dilaksanakan setelah sejumlah konsep dipelajari. Ada baiknya diberikan di kelas-kelas akhir karena banyak konsep yang telah dipelajari oleh siswa. Berikut gambaran pembelajaran analogi matematika

Pertama-tama guru memberikan contoh soal analogi matematika, selanjutnya melalui dialog, siswa dibimbing untuk mengembangkan daya nalarnya.

\section{Analogi Matematika Model 1}

Hubungan antara bilangan

$1 / 3$ dengan barisan

$243,81,27,9$

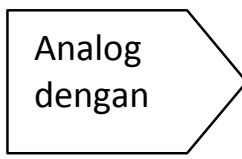

Hubungan antara $\mathrm{p}$ dengan barisan

A. $p+1, p+3, p+9, p+27, \ldots$.

B. $\mathrm{p}, \mathrm{p}^{2}, \mathrm{p}^{3}, \mathrm{p}^{4}$,

C. $3 p, 9 p, 27 p, 81 p$

D. $p-3, p-9, p-27, p-81, \ldots$

Alasan :

Guru : Coba kalian perhatikan pernyataan sebelah kiri, dinamakan apakah barisan tersebut?

Siswa : Barisan geometri

Guru : Baik, nah sekarang coba kalian cari rasionya!

Siswa : Saya bu, rasionya adalah $81 / 243=27 / 81=9 / 27=$ $=1 / 3$

Guru : Baik, sekarang bagaimana kaitan (hubungan) antara 1/3 dengan barisan 243, 81, 27, 9,

Siswa : Kaitan (hubungan) antara $1 / 3$ dengan barisan $243,81,27,9, \ldots \ldots .$. adalah hubungan rasio

Guru : Baik, jadi hubungan yang terjadi pada pernyataan sebelah kiri adalah 
hubungan rasio, dengan demikian analog dengan hubungan antara $\mathrm{p}$ dengan barisan $\mathrm{p}, \mathrm{p}^{2}, \mathrm{p}^{3}, \mathrm{p}^{4}$, (jawaban B) yang juga memiliki hubungan rasio.

\section{Analogi Matematika Model 2}

Selain bentuk soal analogi matematika model 1, kita dapat pula membuat soal analogi yang berbeda yang lebih menuntut daya nalar yang tinggi, seperti bentuk analogi matematika berikut ini.

\begin{tabular}{|c|c|c|c|}
\hline $\begin{array}{l}\text { Hubungan antara } \\
\text { bilangan } 3 \text { dengan } \\
\text { barisan........................ }\end{array}$ & \multirow{5}{*}{$\begin{array}{l}\text { Analog } \\
\text { dengan }\end{array}$} & $\begin{array}{l}\text { Hubungan antara } 1 / p \\
\text { dengan barisan........... }\end{array}$ & $\begin{array}{l}\text { Pilihan } \\
\text { jawaban }\end{array}$ \\
\hline $2,6,18,54, \ldots \ldots \ldots \ldots$ & & $1 / p, 2 / p, 3 / p, 4 / p, \ldots \ldots$ & $\mathrm{A}$ \\
\hline $1,3,9,27, \ldots \ldots \ldots \ldots$ & & $p, p+3, p+6, p+9, \ldots \ldots$ & $\mathrm{B}$ \\
\hline $4,12,36,108, \ldots \ldots \ldots . .$. & & $\mathrm{p}^{4}, \mathrm{p}^{3}, \mathrm{p}^{2}, \mathrm{p}, \ldots \ldots \ldots \ldots$ & $\mathrm{C}$ \\
\hline $7,10,13,16, \ldots \ldots \ldots \ldots$ & & $p, p-3, p-6, p-9, \ldots$ & $\mathrm{D}$ \\
\hline
\end{tabular}

Pembelajaran dapat dilakukan melalui dialog sebagai berikut :

Guru : Perhatikan barisan-barisan bilangan pada pernyataan sebelah kiri, sebutkan masing-masing jenis barisan tersebut!

Siswa : Pada pernyataan sebelah kiri A, B, dan C merupakan barisan geometri, dan D barisan aritmatika

Guru : Baik, selanjutnya carilah jenis barisan yang sama antara pernyataan sebelah kiri dan pernyataan kanan

Siswa : Saya bu !, C merupakan barisan geometri pada pernyataan sebelah kiri dan kanan serta D merupakan barisan aritmatika pada pernyataan sebelah kiri dan kanan

Guru : Baik, nah sekarang tentukan analogi yang terjadi antara pernyataan sebelah kiri dan kanan dengan mencari hubungan antara bilangan 3 dan $1 / p$ dengan barisan di $C$ dan $D$

Siswa : C. Bilangan 3 sebagai rasio pada barisan 4, 12, 36, 108, dan $1 / p$ juga sebagai rasio pada barisan $\mathrm{p}^{4}, \mathrm{p}^{3}, \mathrm{p}^{2}, \mathrm{p}$

D. Bilangan 3 sebagai beda pada barisan $7,10,13,16, \ldots .$. dan $1 / p$ bukan merupakan beda pada barisan p, p-3, p-6, p-9,... sehingga pilihan jawaban yang benar adalah $C$, karena analogi yang terjadi adalah analogi sifat rasio pada barisan geometri 
Aspek kognitif yang diukur dalam pembelajaran analogi matematika adalah kemampuan mencari sifat-sifat hubungan yang terjadi pada suatu konsep dan selanjutnya mencari keserupaan (analogi) diantara dua konsep yang sama atau berbeda.

Duit et.al. (1989) mengemukakan bahwa melalui pembelajaran analogi siswa memperoleh beberapa keuntungan, diantaranya, valuable (bernilai) dalam mempelajari konsep, siswa termotivasi karena menarik perhatian mereka, dan mendorong guru untuk mengetahui pengetahuan prasyarat siswa sehingga miskonsepsi pada siswa dapat terungkap.

\section{Cara /Teknik Membuat Soal Analogi Matematika}

Dalam membuat soal-soal analogi matematika diperlukan kesiapan guru, karena berbeda dengan membuat soal matematika yang rutin. Pada setiap soal analogi matematika termuat konsep yang sama atau berbeda, sehingga dibutuhkan materi yang cukup banyak. Berikut langkah-langkah dalam membuat soal-soal analogi matematika

a. Susunlah semua konsep dalam matematika yang telah dipelajari siswa

b. Susun pula sifat-sifat/hubungan yang terdapat dalam setiap konsep

c. Pilih materi-materi yang mempunyai sifat/hubungan yang dapat dianalogikan.

\section{Penutup}

Penerapan pembelajaran analogi matematika dalam rangka menumbuhkan daya nalar (power of reason)) siswa, memerlukan kesiapan baik dari guru maupun siswa. Bagi guru, sebelumnya perlu mengetahui tingkat kemampuan pemahaman siswa, karena tanpa pemahaman konsep yang baik akan sulit bagi siswa menyelesaikan soal analogi matematika.

Bentuk-bentuk soal analogi matematika sesuai dengan cara pembuatannya, haruslah memenuhi kriteria bahwa sifat-sifat (hubungan) dalam satu konsep yang dapat dianalogikan dengan konsep yang sama atau berbeda. Melalui analogi matematika siswa dilatih untuk menggunakan kemampuan kognitifnya sehingga tumbuh daya nalar yang baik. 


\section{Daftar Pustaka}

Alamsyah (2000). Suatu Pembelajaran untuk Meningkatkan Kemampuan Penalaran Analogi Matematika. Tesis UPI Bandung : Tidak dipublikasikan

Copi, I.M. (1978). Introduction to Logic. New York : Macmillan

Dahlan, J.A. (2004). Meningkatkan Kemampuan Penalaran dan Pemahaman Matematik Siswa Sekolah Lanjutan Tingkat Pertama Melalui Pendekatan Pembelajaran Open-Ended. Disertasi UPI Bandung : Tidak dipublikasikan.

Depdiknas (2001). Kurikulum Berbasis Kompetensi Mata Pelajaran Matematika, Sekolah Menengah Umum. Jakarta : Depdiknas

Duit. et.al. (1989). Teacher Use of Analogies in Their Reguler Teaching Routnes . Research in Science Education 19. 291-299

Kariadinata, R.(2001). Peningkatan Pemahaman dan Kemampuan Analogi Matematika Siswa SMU melalui Pembelajaran Kooperatif. Tesis UPI Bandung : Tidak dipublikasikan

Rustaman, N. (1990). Kemampuan Klasifikasi Logis Anak (Studi Tentang Kemampuan Abstraksi dan Inferensi Anak Usia Sekolah Dasar pada Kelompok Bahasa Sunda). Disertasi PPS IKIP Bandung : Tidak dipublikasikan

Shadiq, F. (2007) Penalaran (Reasoning) : Perlu dipelajari Para Siswa di Sekolah. Mengutamakan Daya Nalar dalam Pendidikan. Yogyakarta : Bagi Prabu

Soekadijo, R.G. (1997). Logika Dasar. Jakarta : Gramedia

Utari,S. (1987). Kemampuan Pemahaman dan Penalaran Matematika Siswa SMA Dikaitkan dengan Kemampuan Penalaran Logic Siswa dan Beberapa Unsur Proses Belajar Mengajar. Disertasi FPS IKIP Bandung : Tidak dipublikasikan. 